\title{
Influence of Motivation and Job Satisfaction on Teacher Creativity in SMA Negeri Region II Jakarta Barat
}

\author{
Daru Rajindra ${ }^{1, a^{*}}$ Neti Karnati ${ }^{1}$, Totok Amin Soefijanto ${ }^{1}$ \\ ${ }_{1}^{1}$ Post Graduate of Education Management, Universitas Negeri Jakarta, Jakarta, Indonesia \\ a darurajindra608@gmail.com \\ ${ }^{*}$ Corresponding Author
}

How to Cite : Rajindra, D., Karnati, N., Soefijanto, T., A. (2020). Influence of Motivation and Job Satisfaction on Teacher Creativity in SMA Negeri Region II Jakarta Barat. International Journal for Educational and Vocational Studies, 2 (1), 19-24. DOI: https://doi.org/10.29103/ijevs.v2i1.2264

\section{ARTICLE HISTORY}

Received:11 October 2019

Revised: 27 December 2019

Accepted: 16 January 2020

\section{KEYWORDS}

Motivation;

Job Satisfaction;

Creativity;

\section{ABSTRACT}

This study aims to determine: (1) The direct effect of motivation on creativity; (2) the direct effect of Job Satisfaction on Creativity; and (3) the direct influence of motivation on job satisfaction. This study uses a survey method with a quantitative approach which is carried out using a path analysis technique. The unit of analysis in this study was all ASN Educators at SMA Negeri Region II Jakarta Barat with a sample size of 98 people selected with regard to a level in the population element (stratified random sampling). The results showed that: (1) there was a positive direct effect between motivations on creativity; (2) there is a positive direct effect between job satisfactions on creativity; and (3) there is a positive direct effect between motivations on job satisfaction.

This is an open access article under the CC-BY-SA license.

\section{INTRODUCTION}

Education in a policy perspective is a conscious effort planned to create an atmosphere of learning, and process so that students can actively develop the potential to have spiritual strength, self-control, personality, intelligence, noble character, and skills. As stated in UU No. 20 of 2003 concerning National Education System that the teacher is a professional educator with the main task of educating, teaching, guiding, directing, training, evaluating, and evaluating students in formal education, namely: basic education, secondary education, and upper education. The creative teacher is concluded in the news (Kompasiana, 2016) that the creative teacher as a teacher regularly puts himself in with new ideas that arise from various sources. Teachers who are still less creative are teachers who are still having difficulty coping with change, that is, those who keep repeating old obsolete ideas with very little imagination and creativity. Creative teachers always have something new for the students' trust. Creativity can be interpreted as the ability to create and be creative. There is a question why should a teacher be a creative person? There are several reasons why teachers must be creative; a) Creativity is the fastest alternative bridge to achieve learning objectives. b) Through creativity, life will be more challenging to go through. c) Together with creativity, the satisfaction obtained becomes higher.
Creative education is a learning process that requires teachers to motivate and bring up the creativity of students throughout the learning process, using a variety of methods and strategies, such as group work, problem-solving and so on. Creative education requires teachers to be able to stimulate students to bring up creativity both in the context of creative thinking and in the context of creative doing something. Creative thinking is an imaginative but rational ability. It can also be known several factors that influence the quality of the educational process and outcomes, including curriculum, teachers, educational facilities and infrastructure, environment, education management, and the potential of the child himself. But of the various factors that influence the quality of education, the teacher factor is the most important, it can even be said to be a key factor in the success of education. The teacher is a component that determines the quality of education, and the teacher is the key to developing the quality of education.

Some facts related to the creativity of the state civil service teacher (ASN) in region II Jakarta Barat are quoted from the news media that conventional learning methods are still widely used in a variety of classroom learning at every level of education. Some teachers are not accustomed to modern learning methods which may 
syntactically (stages of learning) have various characteristics and requirements. This makes some teachers feel difficult when applying modern learning methods. Likewise with students, because they are accustomed to carrying out learning conventionally (listening, taking notes, working on problems, collecting) causing them to become unfamiliar when given learning with modern learning methods. Finally, they feel confused and unenthusiastic when learning (Kompasiana, 2018), this shows that the teacher is still experiencing difficulties in being creative so that it considers the difficulty of a change from conventional learning to modern learning.

In data provided by The United Nations Development Program (UNDP) noted in 2018 that Indonesia ranked 116 out of 189 countries, this observation aims to ensure consistency in reporting on human development indexes and statistics. This includes an analysis of the state of human development and a portrait of current conditions as well as long-term trends in human development indicators. The importance of the teacher's role is even contained in a Republika daily newspaper: Teachers are an important element amid a country's life. Its existence has an influence that reaches various aspects of life. To illustrate this, one well-known Vietnamese figure, Ho Chi Minh, dared to state, "No Teacher, No Education. No Education, No Economic and Social Development."

Quoted from the news (tirto.id, 2017) according to education counselor Itje Chodijah revealed the many educational problems that are still being experienced about the problem of low teacher motivation in the Jakarta Barat area, in improving the quality of teaching and developing also experienced by DKI Jakarta. According to him, teachers in DKI Jakarta who have high TKD are not matched by quality. "The proof is now DKI, a state teacher with a high TKD, is it compatible with quality? Nope DKI has a large regional allowance but it is not compatible with quality, "he added. According to him, from the majority of state teachers who received high Regional Performance Allowances (TKD), the majorities considered them as rights but were not accompanied by similar obligations. As a commemoration of National Education Day, he appealed to the community as a whole to make national education day commemoration as a turning point in improving the quality of Indonesian education. Indonesian education according to evaluations from various international institutions, he continued, still shows that the national education index is still weak.

In the implementation, researchers look to the field that the problems that are within the scope of the education level of the State High School (SMA) in Region II, Jakarta Barat, namely: 1) ASN teachers in high schools Region II, Jakarta Barat experience productivity and creativity problems. 2) There are still many ASN teachers who experience low motivation resulting in low results to be achieved. 3) Creativity has an impact on the work motivation and job satisfaction of ASN teachers, as evidenced by the decreasing results of creativity and teacher productivity to transfer knowledge to students. While creativity should be the main thing for a teacher, not motivated by a teacher and teacher job satisfaction is closely related to the creativity that will be done.

It was also strengthened that creativity is a key, quoted in (Kompas, 2019) that high reasoning based learning requires creative teachers to be able achieve their goals effectively. This method is also to be easily accepted by students. The 2013 curriculum which is based on the development of high-level reasoning has changed the pattern of learning in schools. The mindset and learning strategies that were initially centered on the teacher have now become student-centered. As the spearhead of this change, teachers are required to be more creative and innovative in presenting subject matter. Teachers must also have broad insights and continue to learn to face the changing times. Thus, teachers will be able to formulate questions that contain contextual problems as demanded in higher-order thinking systems (HOTS) based on Curriculum 2013.

\section{METHODS}

This study uses a quantitative approach as survey methods. Analysis of the data used path analysis. This technique was chosen with consideration to examine the relationship between variables that determine the direct effect of the independent variables on the dependent variable. This study examines the effect of the variables $\mathrm{X} 1$ and $\mathrm{X} 2$ on the variable X3 and measures the effect with the Pearson calculation method.

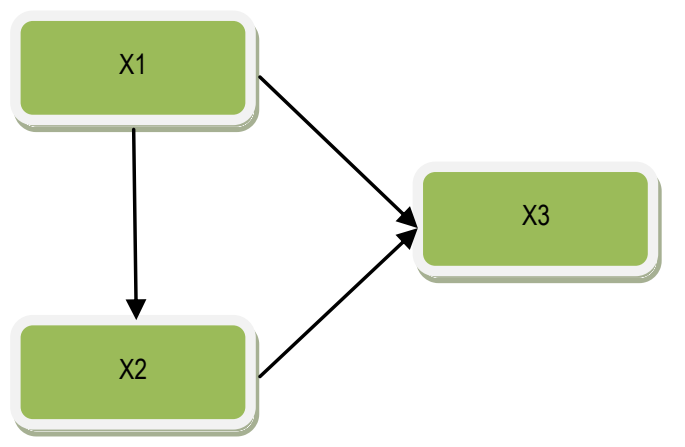

Fig 1. Research Design

Note: $\longrightarrow$ : Direct Influence

Data were taken in the field with the form of quantity numbers, which will then be processed statistically. According to statistical rules the treatment of processing data needed. Starting testing the reliability and validity of data, produce the real data so that it can be exchanged. Next is normality prerequisite test and regression analysis to examine the effect between variables.

The population in this study was all ASN high school teachers in Jakarta Barat Region II, there were 4 districts, 
namely Kembangan, Kebon Jeruk, Palmerah, and Grogol Petamburan, and had a total of 53 public and private high schools. This study focuses on State schools in Jakarta Barat Region II with a total of 8 state high schools with a total population of 394 ASN teachers. The research sample was 198 people. To determine the sample using the Slovin formula, the Slovin formula is used to calculate the sample size that is considered to represent the population. Furthermore, the sampling technique of 198 respondents as a sample in this study uses a technique stratified random sampling, which is a sample about a level in the population element.

\section{RESULTS AND DISCUSSION}

The collect of data research in this study is classified into the type statistics parametric which requirement the analyzed of each variable data research must set to a normal distribution. The testing hypothesis on this study use Path analysis. Path analysis requires that each regression equation of the constellation must meet the testing process of analysis requirements (assumptions). Therefore before testing the hypothesis, first the requirements of the test are carried out. Some statistical tests that must be met by data in path analysis are (1) Normality Test, (2) Significance and Regression Linearity Test. The data used in compiling the regression model must meet the assumption that the data come from normally distributed populations. The normality distributed testing is performed using the Liliefors Test technique. The testing criteria reject $\mathrm{H} 0$ which states that the score is not normally distributed if the Lcount is smaller than the Ltable. From the results of the study, it can be seen that the maximum IF(Zi)-S(Zi)I concluded with the Lcount for the three error estimated regression is smaller than the Ltable value, the rejection limit $\mathrm{H} 0$ listed in the Liliefors table at $\alpha=0.05$ and $n=198$ is $\frac{0,063}{\sqrt{n}}$.

\subsection{Test for Normality of Estimated Regression X3 over X1}

From the calculation results, the value of Lcount $=0.062$, this value is smaller than the value of Ltable $(\mathrm{n}=198$; $\alpha=$ 0.05) 0.063. Considering that the Lcount value is smaller than Ltable, then the error data distribution of estimated Regression X3 (Creativity) over X1 (Motivation) tends to form a normal curve.

\subsection{Test for Normality of Estimated Regression X3 over X2}

From the calculation results, the value of Lcount $=0.059$, this value is smaller than the value of Ltable ( $\mathrm{n}=198$; $\alpha=$ 0.05) 0.063. Considering that the Lcount value is smaller than the Ltable, the estimated error distribution data of Regression X3 (Creativity) over X2 (Job Satisfaction) tends to form a normal curve.

\subsection{Test for Normality of Estimated Regression X2 over X1}

From the calculation results, the value of Lcount $=0.052$, this value is smaller than the value of Ltable $(n=198$; $\alpha=$
0.05) 0.063. Considering that the Lcount value is smaller than Ltable, then the distribution of error data is estimated Regression X2 (Job Satisfaction) over X1 (Motivation) tends to form a normal curve.

Based on the above calculation, it can be concluded that all the H0 hypotheses which contain samples from abnormal distribution populations cannot be accepted or the H0 hypothesis is rejected. In other words that the selected sample comes from a normally distributed population. The recapitulation of the normality test results is listed in the following table:

Table1. Test Results for Regression Estimation Normality Errors

\begin{tabular}{cccccc}
\hline \multicolumn{3}{c}{ Estimated Error } & \multicolumn{2}{c}{ Ltable } & \\
\cline { 1 - 5 } Regression & $\mathbf{N}$ & Lcount & $\mathbf{\alpha}=0,05$ & $\mathrm{a}=0,01$ & \\
\hline $\mathrm{X} 3-\mathrm{X} 1$ & 198 & 0,062 & 0,063 & 0,073 & Normal \\
\hline $\mathrm{X} 3-\mathrm{X} 2$ & 198 & 0,059 & 0,063 & 0,073 & Normal \\
\hline $\mathrm{X} 2-\mathrm{X} 1$ & 198 & 0,052 & 0,063 & 0,073 & Normal \\
\hline
\end{tabular}

Based on the values of Lcount and Ltable above it can be interpreted as a combination of all data both Creativity on Motivation, Creativity on Job Satisfaction, and Motivation on Job Satisfaction derived from samples that are normally distributed.

\subsection{Test of Significance and Linearity of Regression}

The research hypothesis testing was carried out using regression and correlation analysis techniques. Regression analysis is used to predict the relationship model, while correlation analysis is used to determine the degree of influence between research variables.

In the initial stage, the submission of a hypothesis is to state the effect of each exogenous variable on endogenous variables in the form of a simple regression equation. The equation is determined by using the resulting data with measurements in the form of a combination of variables with endogenous variables such that the regression equation model is the most suitable form of relationship. Before using the regression equation to conclude hypothesis testing, the regression model obtained was tested for its significance and linearity by using the Ftable test in the ANAVA table. The criteria for testing the significance and linearity of the regression model are set as follows:

Regression significance: Fcount $\geq F$ table on the regression line. Linear regression: Fcount $<$ Ftable on the tuna line matches. The next step is to perform a correlation analysis by reviewing the level and significance of the relationship between combinations of exogenous variables and endogenous variables. 


\subsection{Significance and Linearity Test of Creativity Regression Equations for Motivation}

From the calculation data of the regression equation model between Creativity and Motivation, the regression constant $a=62.71$ and the regression coefficient $b=0.510$ thus the relationship of the simple regression equation model is $\mathrm{X}^{\wedge} 3=62.71+0.510 \mathrm{X} 1$. Before the regression equation model is analyzed further and used in concluding, the significance and linearity of the regression equation had tested. Regression equation X3 $=62.71+0.510 \mathrm{X} 1$, for the significance test obtained Fcount 100.12 is greater than Ftable $(0.01 ; 1: 190) 6.77$ at $\alpha=0.01$ because Fcount $>$ Ftable then the regression equation is declared very significant. For the linearity test, the Fcount of 1.35 is smaller than the Ftable $(0.05 ; 55: 135)$ of 1.41 at $\alpha=0.05$. Because Fcount $<$ Ftable, the estimated point distribution forming a linear line is acceptable.

\subsection{Significance and Linearity Test of Creativity Regression Equations for Job Satisfaction}

From the calculation data of the regression equation model between Creativity and Job Satisfaction obtained regression constants $a=47.29$ and the regression coefficient $b=0.574$ thus the relationship of the simple regression equation model is $\mathrm{X}^{\wedge} 3=47.29+0.574 \mathrm{X} 2$. Before the regression equation model is analyzed further and used in concluding, the significance and linearity of the regression equation had tested. Regression equation $\mathrm{X}^{\wedge} 3=47.29+0.574 \mathrm{X} 2$, for the significance test obtained Fcount is 112.03 greater than Ftable $(0.01 ; 1: 190) 6.77$ at $a=0.01$ because Fcount $>$ Ftable then the regression equation is declared very significant. For the linearity test, the Fcount of 93.33 is smaller than the Ftable (0.05; 55: 135 ) of 1.43 at $a=0.05$. Because Fcount $<$ Ftable, the estimated point distribution forming a linear line is acceptable.

\subsection{Significance and Linearity Test of Motivation Regression Equations for Job Satisfaction}

From the calculation data of the regression equation model between Motivation and Job Satisfaction obtained regression constants $\alpha=94.25$ and the regression coefficient $b=0.376$ thus the relationship of the simple regression equation model is $\mathrm{X}^{\wedge} 2=94.25+0.376 \mathrm{X} 1$. Before the regression equation model is analyzed further and used in concluding, the significance and linearity of the regression equation had tested. Regression equation $\mathrm{X}^{\wedge} 2=94.25+0.376 \mathrm{X} 1$, for the significance test obtained Fcount 38.89 is greater than Ftable $(0.01 ; 1$ : 190) 6.77 at a $=0.01$ because Fcount $>$ Ftable then the regression equation is declared very significant. For the linearity test, the Fcount is 1.40 smaller than the Ftable (0.05; 55: 135) of 1.41 at $\alpha=0.05$. Because Fcount $<$ Ftable, the estimated point distribution forming a linear line is acceptable. It can be seen that the correlation between motivation and job satisfaction is 0.407 , the correlation between motivation and creativity is 0.581 , the correlation between job satisfaction and creativity is 0.603 .

\subsection{First Hypothesis}

Motivation has a direct positive effect on Creativity.

$$
\begin{aligned}
& \text { H0: } B 31 \geq 0 \\
& \text { H1: } B 31>0 \\
& \text { H0 is rejected if tcount < ttable. }
\end{aligned}
$$

From the results of the path analysis calculation, there was a direct influence of Motivation on Creativity, the value of the path coefficient is 0.403 and the calculated coefficient value is 7.259. The coefficient value table for $a$ $=0.05$ was 1.97 . Because the t-coefficient value is greater than ttable, $\mathrm{H} 0$ is thus rejected and $\mathrm{H} 1$ is accepted. Thus, the first research hypothesis that motivation has a direct positive effect on creativity is acceptable. Based on this hypothesis, it can be concluded, the increase in motivation will be followed by creativity.

\subsection{Second Hypothesis}

Job Satisfaction has a positive direct effect on Creativity.

$$
\begin{aligned}
& \text { H0: } B 32 \geq 0 \\
& \text { H1: } B 32>0 \\
& \text { H0 is rejected if tcount < ttable. }
\end{aligned}
$$

From the results of the path analysis calculation, there was a direct effect of Job Satisfaction on Creativity, the value of the path coefficient of 0.439 and the value of the t-coefficient of 7.916. The coefficient value table for $a=$ 0.05 was 1.97. Because the t-coefficient value is greater than ttable, H0 is thus rejected and H1 is accepted. Thus, the first research hypothesis that Job Satisfaction has a direct positive effect on Creativity can be accepted. Based on this hypothesis, it can be concluded, an increase in Job Satisfaction will be followed by Creativity.

\subsection{Third Hypothesis}

Motivation has a positive direct effect on job satisfaction.

$$
\begin{aligned}
& \mathrm{H} 0: B 21 \geq 0 \\
& \mathrm{H} 1: B 21>0 \\
& \mathrm{H} 0 \text { is rejected if tcount < ttable. }
\end{aligned}
$$

From the results of the path analysis calculation, there was a direct effect of Motivation on Job Satisfaction, the value of the path coefficient of 0.407 and the coefficient of tcount of 6.324. The coefficient value table for $\alpha=0.05$ was 1.97. Because the t-coefficient value is greater than ttable, $\mathrm{H} 0$ is thus rejected and $\mathrm{H} 1$ is accepted. Thus, the first research hypothesis that motivation has a direct positive effect on job satisfaction can be accepted. Based on this hypothesis, it can be concluded, the increase in motivation will be followed by job satisfaction. 


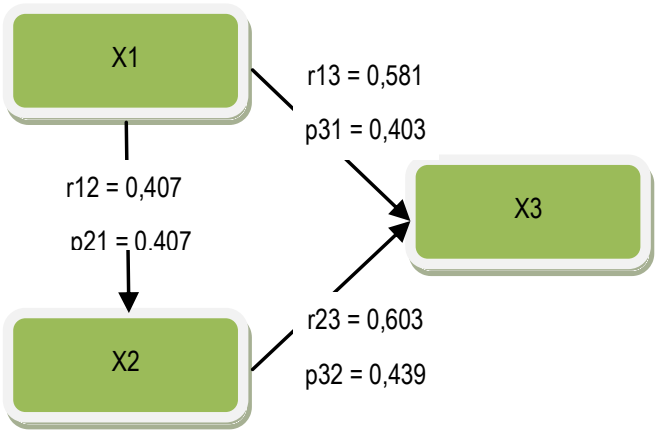

Fig. 2 Empirical Model between Variables

\section{CONCLUSION}

Based on the results of calculations and analysis of research data that has been described above, then several conclusions can be obtained as follows:

1. Motivation has a direct positive effect on creativity. This means that high motivation will affect the increase in teacher creativity in Region II High Schools in Jakarta Barat.

2. Job satisfaction has a direct positive effect on creativity. This means that high job satisfaction will affect the level of teacher creativity in Region II High Schools in Jakarta Barat.

3. Motivation has a positive effect on job satisfaction. The meaning of that high motivation will affect the increase in Job Satisfaction of teachers in Region II High Schools in Jakarta Barat.

The conclusions of the results of this study indicate that there is a positive direct effect of Motivation and Job Satisfaction on Creativity. Considering the importance of creativity for a teacher in achieving educational goals, then as an implication, the researcher suggests a follow-up effort to improve the behavior through the treatment of teacher motivation and job satisfaction variables, as follows:

1. Enhancing Creativity through Motivation can be through the following things:

a. Always provide psychological support to teachers who have creativity began to decline, to find out that is supervision that must be diligently done to find out what happened in the field.

b. Conduct psychological coaching for teachers even though the individual teacher does not seem to have a problem, the principal has the full right to do so.

c. Hold rewards and punishments in the form of practical gifts or the like for teachers who have a high level of creativity.

d. Encourage that every teacher can have a teaching strategy by giving an individual approach.

e. Avoid direct execution by the principal of the teacher who is teaching
2. Efforts to improve teacher creativity through job satisfaction can be done by:

a. An organizational climate is one of the ways to increase job satisfaction that will spur in the spirit of teaching to create teaching creativity, the principal's duty to make the organization at the school soothing.

b. For the government to often hold a program for teachers to take part in creative competitions as a breakthrough in teaching in the future that affects the teacher's career or benefits.

c. Giving fostering in the form of class promotion to teachers who have achievements at a certain level by creating teaching innovations or have made government agencies proud.

\section{REFERENCES}

Ahmad, M.A.Roshidi (1999). Pengaruh Iklim Organisasi Ke Atas Kepuasan Kerja Guru-Guru Sekolah Menengah. Kajian Kes Di Daerah Padang Terap, Kedah, Tesis Sarjana Sains Fakulti Sains Kognitif Dan Pembangunan Manusia University Malaysia Sarawak, Malaysia: Penerbit Kailifa.

Duică, A. (2008), Managemen, Editurabibliotheca, targoviste.

http://hdr.undp.org/en/2018-update

https://kompas.id/baca/humaniora/2019/05/03/kreativitasguru-menjadi-kunci

https://tirto.id/motivasi-peningkatan-kualitas-mengajar-g uru-indonesia-rendah-cnRP

https://www.kompasiana.com/altip/5c0db2cbab12ae71c83 61e04/saatnya-tinggalkan-metode-pembelajaran-kon vensional?page $=$ all

Kemal, Isthifa; Setyanto, Eddy. The Effectivenes of Managerial Skills of State Elementary School Principals in East Jakarta. Jurnal Ilmiah Peuradeun, [S.1.], v. 5, n. 2, p. 157-168, may 2017. ISSN 2443-2067. Available at: $<$ https://journal.scadindependent.org/index.php/jipeu radeun/article/view/133>. Date accessed: 15 nov. 2019. doi: http://dx.doi.org/10.26811/peuradeun.v5i2.133.

Kemal, Isthifa; Suryadi, Suryadi; Rosyidi, Unifah. Management of Lecturers Resource Development at Higher Eduction. International Journal of Higher Education.doi: https://doi.org/10.5430/ijhe.v8n5p246. http://www.sciedupress.com/journal/index.php/ijhe/ar ticle/view/16014

Lubart, T. I. (1994). Creativity. In R. J. Sternberg (Ed.), Handbook of Perception and Cognition: Thinking and Problem Solving. New York: Academic Press.

Munandar, Utami SC, (1992). Mengembangkan Bakat Dan Kreativitas Anak Sekolah. Jakarta: Grasindo

Robbins, Stephens P, (1996), Perilaku Organisasi, Jilid 1 Dan 2, Prehallindo, Jakarta. 
Torrance, E.P., \& safter, H.T. (1999). Making The Creative Leap Beyond. United States: Creative Education Foundation Press

Usman, Husaini, (2013). Manajemen: Teori, Praktek, Dan Riset Pendidikan, Jakarta: Bumi Aksara. 